\title{
ANALISE DO HINO NACIONAL BRASILEIRO UM IMPORTANTE RECURSO PARA COMPREENSÃO DA INDEPENDÊNCIA DO BRASIL
}

\author{
João Victor Nogueira Okido' \\ Ana Enedi Prince ${ }^{2}$
}

Resumo: Este artigo tem como função explorar mais nosso patriotismo e tornar o Hino Nacional como ferramenta deste estudo, A composição do nosso Hino Nacional foi inspirada no pensamento positivista, citando os acontecimentos da pré e pós-Independência do Brasil, tornando-se conhecido e popular por volta do ano de 1831, com o título de "Hino ao Sete de Abril", data em que o Imperador D. Pedro I abdicou da coroa em nome de seu filho D. Pedro II. Foi escrito de uma forma na qual só seria possível um verdadeiro brasileiro capaz de entender. Todos, por uma questão de patriotismo, devem aprendê-lo e, ao analisá-lo de forma correta, podemos compreender o significado de seu conteúdo. A análise completa do Hino, comparando seus versos com a Independência de nosso país é o objetivo principal deste artigo.

Palavras-chave: Hino Nacional; Independência do Brasil; História do Brasil.

\footnotetext{
1 Universidade do Vale do Paraíba, Brasil. E-mail: joao-okido@hotmail.com.

2 Universidade do Vale do Paraíba, Brasil. E-mail: prince@univap.br.
} 